\title{
Re-colonization by the Macroinvertebrate Community after a Drought Period in a First-Order Stream (Agüera Basin, Northern Spain)
}

\author{
Ainhoa Otermin, Ana Basaguren and Jesús Pozo \\ Laboratorio Ecología, Departamento de Biología Vegetal y Ecología, Universidad del País Vasco, Apdo. 644, \\ 48080 Bilbao.
}

\begin{abstract}
The effect of a drought on the inacroinvertebrate community was studied in a 1st order tributary ofthe Agüera stream (northern Spain), from November 1995 to May 1996. During the dry period taxa richness was very low. Chironomidae, Ceratopogonidae, Odonata, Oligochaeta and Mollusca were recorded in the streambed. Non-flying taxa were dominant in density and biomass at the beginning of the re-coloniaation process, indicating that these taxa are more resistant to drought than flying taxa. Thereafter, flying taxa became more abundant. Taxa hatching in winter (Capnioneura and Glossosomatidae) seem to be less affected by the drought and developed dense populations. Invertebrate density and biomass increased significantly over time, becoming a quite diverse coinmunity by the end of the study period.
\end{abstract}

Keywords: Disturbance, drought, macroinvertebrates, community, re-colonization

\section{Resumen}

Se estudió el efecto de un periodo de sequía sobre la comunidad de macroinvertebrados de un tributario de prinier orden del rio Agüera (norte de España), el periodo de estudio fue de noviembre de 1995 a mayo de 1996. Durante el periodo en el que el arroyo estaba seco la riqueza taxonómica era muy baja y sólo se encontraron en el lecho quironómidos, odonatos. oligoquetos y moluscos. Al comienzo del proceso de recuperación los taxones no voladores dominaban en densidad y biomasa, lo cual indica que estos taxones fueron más resistentes u la sequia que los voladores. Posteriormente, los taxones voladores incrementaron su importancia. Taxones que eclosionaron en invierno (Capnioneura y Glossosomatidae) se vieron menos afectados por la sequía y desarrollaron densas poblaciones. La densidad y biomasa de los invertebrados se incrementó significativamente u lo largo del tiempo. alcanzándose una comunidad más diversa al final del periodo de estudio.

Palabras clave: Perturbación. sequía, macroinvertebrados, comunidad recolonización

\section{INTRODUCTION}

Streams under natural conditions are exposed to variations in flow at different temporal and spatial scales (Resh et al. 1988). When these changes remove organisms and open up spaces or other resources that can be utilised by individuals of the same or different species they are nained disturbances (Townsend \& Hildrew, 1994).

Droughts are very common features in temporary lotic systems. Williams (1987) defined these systeins as natural watercourses that experience recurrent dry phases of variable duration. The biota are exposed to a suite of adverse environmental conditions and alterations in the biotic interactions during the dry period. Drought conditions frequently lead to intolerable thermal stress and/or low dissolved oxygen levels for inacroinvertebrates before the entire stream dries up (Gricwold et al., 1982; Collier, 1995; Velasco \& Millán, 1998). When the disturbance is strong enough, habitats can be restricted to isolated 
pools where interactions can be enhanced. As a consequence, species richness decreases before the total drying up of the channel (Boulton et al., 1992; Maltchik \& Silva-Filho, 2000).

Drying of stream channels normally occurs gradually, allowing time for behavioural adaptations. In this type of stressed stream, many macroinvertebrates have evolved life history or behavioural characteristics that enhance their survival or recovery. Among these, most successful adaptations are those related to life cycle (e.g. diapause states or resisting forms), to the ability to seek refuge from dryness in the hyporheic zone and to the dispersion capacity (Williams, 1987, 1996; Boulton, 1989). Dispersion capacity is linked to re-colonization strategies employed by the macroinvertebrates: drift, upstream migration, aerial migration or oviposition and upward movements from the substrate or hyporheic zone (Williams, 1977; Cushing \& Gaines, 1989; Yount \& Niemi, 1990; Mackay, 1992; Ilg et al. 2001). The contribution of each pathway to the re-colonization process depends on the magnitude of the disturbance, the season in which this occurs, and the distance to undisturbed zones (Gore, 1982; Cushing \& Gaines, 1989). Many authors (e.g. Angradi 1997; Matthaei et al., 1999) suggest that the recovery of the benthic community following disturbance is also related to the abundance of

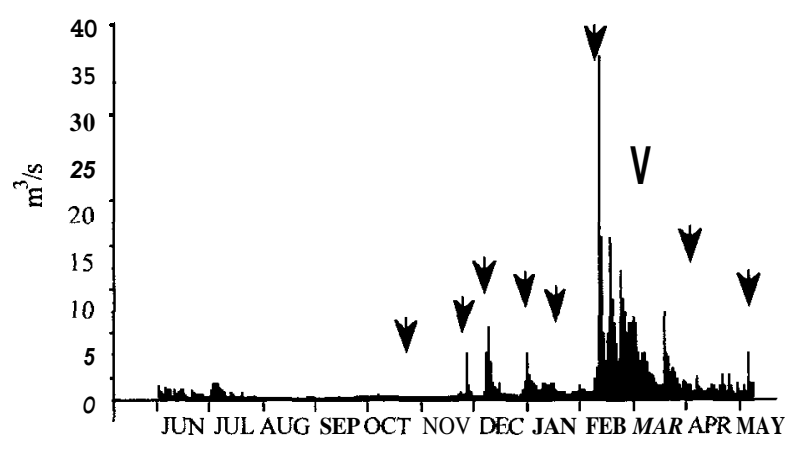

Figure 1. Daily discharge at a gaiiging station at the mouth of the Agüera basin (Northem Spain) from June 1995 to May 1996. Arrows indicate sampling dates. Caudal diario en una estación de aforo de la cuenca del Agüera de Junio de 1995 a Mayo de 1996 Las flechas indican fechas de muestreo. refugia, including organic debris dams, deep interstitial habitat, and first-order tributaries.

Several attributes of the Aguiera stream basin have been studied and different investigations have shown the effect of spates on the physicochemical characteristics of the water, and the stream communities (Elósegui \& Pozo, 1994; Basaguren et al., 1996). However, the effects of drought on the macroinvertebrate community and its recovery remain unstudied in this type of system, usually with a permanent flow. The aim of the present work is to approach an understanding of the recovery dynamics of the macroinvertebrate community after a drought period in a nonintermittent stream of the Agüera basin.

\section{METHODS}

\section{Study site}

The study was conducted in a 32-m long reach of the Jerguerón, a first-order tributary of the Agüera stream, in Northern Spain (43'1 9'00'N, $\left.3^{\circ} 15^{\prime} 46^{\prime \prime} \mathrm{W}\right)$. The Agüera stream watershed covers an area of $144 \mathrm{Km}^{2}$. The climate is temperate humid, with an annual rainfall of $1,650 \mathrm{~mm}$ and mean temperature of $11^{\circ} \mathrm{C}$. The geological substratum of the basin is mainly siliceous, with calcareous materials in mid reaches.

The Jerguerón stream drains a catchment of 83 ha before meeting the Aguiera, flowing through an Eucalyptus globulus Labill plantation. Substrate is dominated by boulders $(25.6 \mathrm{~cm}-1 \mathrm{~m}$ in diameter) and gravel $(0.2 \mathrm{~cm}-6.4 \mathrm{~cm}$ in diameter). Data on water physico-chemistry during the study period

Tabla 1. Mean and range of variation of physico-chernical characteristics (i.e. temperature, $\mathrm{pH}$, conductivity and $\mathrm{O}_{2}$ saturation) of the Jerguerón stream during the study period (June 1995-May 1996) Características fisico-químicas (media y rango de variación) en el arroyo Jerguerón durante el periodo de estudio.

\begin{tabular}{lrr} 
Temperature (“C) & 9.7 & $(7.2-13.2)$ \\
pH & 6.1 & $(5.5-6.3)$ \\
Conductivity (mS cm-1) & 69.4 & $(67.4-91)$ \\
\% oxygen caturation & 92.3 & $(73-102)$ \\
\hline
\end{tabular}


are summarised in Table 1. This stream has an irregular hydrologic regime, becoming dry during some suminers. The studied reach remained dry for three months, from mid August to mid November 1995. The entire channel of this tributary dried up from September to November (i.e. a month and a half). Water flow was restablished after the autumn rains. The daily discharge registered at a gauging station in the mouth of the basin, from June 1995 to May 1996, is shown in Figure 1.

\section{Macroinvertebrate sampling}

Qualitative samples were taken in October 1995 from the hyporheic zone to a depth of $10 \mathrm{~cm}$ to assess the composition of the remaining benthic community. The channel was dry but the substrate taken was still wet. Immediately after the re-establishment of the water flow in November, the macroinvertebrate community was sampled using a Surber net $\left(0,09 \mathrm{~m}^{2}, 200 \mathrm{~mm}\right.$ mesh $)$ at 5 randomly selected points along the 32-m study reach and preserved in $4 \%$ formaldehyde. Samples were collected on eight dates from 23 November to 4 May, every two weeks at the beginning of the study (until the $5^{\text {th }}$ sampling date, on 5 February), when major and rapid changes are expected to occur in the community structure, and monthly thereafter.

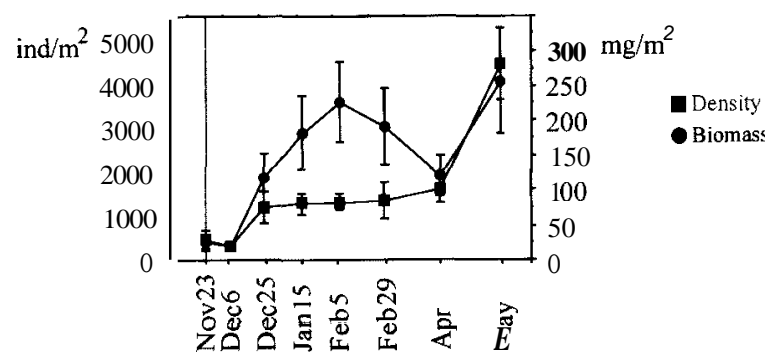

Figure 2. Mean abundance and biomass of total invertebrates in a first-order stream in the Agüera basin (Norihern Spain) over the study period (June 1995 to May 1996). Vertical bars are of one standard error at either side of the mean. Abundancia y biomusa media del total de invertebrados a lo largo del periodo de estudio. En barras se representa el error estándar.

\section{Macroinvertebrate densities and biomass}

In the laboratory, samples were washed through 1 $\mathrm{cm}, 1 \mathrm{~mm}$ and $200 \mathrm{~mm}$ nested sieves. Macroinvertebrates were sorted, identified to genus or family (Richoux, 1982; Puig, 1983; Tachet et al., 2002), and counted. Macroinvertebrates were oven-dried at $60^{\circ} \mathrm{C}$ to constant weight, and biomass was expressed in terms of dry mass (DM). Temporal differences in density and biomass of the most abundant taxa (i.e. those representing at least $4 \%$ of total density on any sampling date) were examined using a one-way ANOVA on log $(\mathrm{x}+1)$ transformed data, and a Tukey test for multiple-comparisons (Zar, 1984). Temporal dynamics of the community structure during the study period were compared with data from a previous study over an equivalent but flowing period in 1992-1993 (unpublished data).

\section{RESULTS}

Taxonomic richness was low in the hyporheic zone during the drought period. A month before the re-establishment of flow only small dipterans (Chironomidae and Ceratopogonidae), odonates, oligochaetes and Mollusca (Potamopyrgus) were recorded.

A total of 41 taxa were identified during the study period (Table 2). The number of taxa increased with time. At the first sampling date we found 17 taxa: Diptera (4 families), Plecoptera (2 genera), Trichoptera (3 families), Coleoptera (3 genera), Oligochaeta, Crustacea (1 genus), Mollusca (2 genera) and Nematoda. On the last sampling date there were 28 taxa: Diptera (6 families), Plecoptera (5 genera), Ephemeroptera (4 genera), Trichoptera (2 families), Coleoptera (4 genera), Odonata (1 genus), Oligochaeta, Crustacea (2 genera), Mollusca (2 genera) and Nematoda.

Mean macroinvertebrate density and biomass increased significantly over time (Table 3 , Fig. 2). From November to May density changed from 457 ind $\mathrm{m}^{-2}$ to 4446 ind $\mathrm{m}^{-2}$, and biomass from $24.4 \mathrm{mg} \mathrm{m}^{-2}$ to 257.6 ing $\mathrm{m}^{-2}$. 
Table 2. Mean inacroinvertebrate density (ind $\mathrm{m}^{-2}$ ) and richness during the sampling period (June 1995-May 1996) in a first-order stream in the Aguiera basin (Northern Spain). NF: non-tlying taxa. F: flying taxa. Densidad media de los mucroinvertehrados y riqueza en cada fecha de muestreo (los datos están expresados en individuos por $m^{2}$ ). $N F$ : taxones no voladoses. F: taxones voladores.

\begin{tabular}{|c|c|c|c|c|c|c|c|c|}
\hline & 23111195 & 6112195 & 2512195 & 1511196 & $5 / 2 / 96$ & 2912196 & $1 / 4 / 96$ & $4 / 5 / 96$ \\
\hline \multicolumn{9}{|l|}{ Cl. INSECTA } \\
\hline \multicolumn{9}{|l|}{ DIPTERA } \\
\hline Chironomidae & 113.3 & 48.9 & 131.1 & 240.0 & 413.3 & 393.3 & 622.2 & 1411.1 \\
\hline \multicolumn{9}{|l|}{ Tipulidae } \\
\hline Athericidae & & 2.2 & 2.2 & 2.2 & 2.2 & 2.2 & 2.2 & 6.7 \\
\hline Tabanidae & & & & & & 6.7 & 2.2 & \\
\hline Simuliidae & 8.9 & & 11.1 & 17.8 & 82.2 & 186.7 & 11.1 & 148.9 \\
\hline Ceratopogonidae & 6.7 & 13.3 & 22.2 & 6.7 & 22.2 & 22.2 & 24.4 & 13.3 \\
\hline Limoniidae & 8.9 & 8.9 & 13.3 & 20.0 & 31.1 & 17.8 & 26.7 & 6.7 \\
\hline Dixidae & & & & & & & & 2.2 \\
\hline \multicolumn{9}{|l|}{ PLECOPTERA } \\
\hline Protonemura & & & & & & 2.2 & & 2.2 \\
\hline Capnioneura & 4.4 & 62.2 & 295.6 & 166.7 & 15.6 & 11.1 & 24.4 & 931.1 \\
\hline Leuctra & & & 2.2 & 2.2 & 4.4 & 2.2 & 17.8 & 95.6 \\
\hline Siphonoperla & 2.2 & 2.2 & 4.4 & 2.2 & 4.4 & & & 2.2 \\
\hline Isoperla & & & & & 4.4 & & & 6.7 \\
\hline \multicolumn{9}{|l|}{ EPHEMEROPTERA } \\
\hline Baetis & & 2.2 & & & 4.4 & 4.4 & 15.6 & 75.6 \\
\hline Leptophlebiidae & & 2.2 & & & 13.3 & 22.2 & 364.4 & 417.8 \\
\hline Ecdyonurus & & & & & & & 2.2 & 4.4 \\
\hline Rhithrogenu & & & & & 2.2 & & & 11.1 \\
\hline \multicolumn{9}{|l|}{ TRICHOPTERA } \\
\hline Rhyacophila & 4.4 & 4.4 & 17.8 & 2.2 & 2.2 & 4.4 & & \\
\hline Glossossomatidae & & 4.4 & 84.4 & 286.7 & 160.0 & 60.0 & 42.2 & 44.4 \\
\hline Hydroptila & & & & & & 2.2 & 2.2 & \\
\hline Psychomyidae & 2.2 & 2.2 & & & 2.2 & & & \\
\hline Polycentropus & & & 2.2 & 2.2 & 2.2 & & 4.4 & \\
\hline Polycentropodidae & & & & & 2.2 & 2.2 & & 2.2 \\
\hline Plectrocnemia & 2.2 & & & & & & 2.2 & \\
\hline Limnephi lidae & & & 6.7 & 2.2 & 8.9 & & 4.4 & \\
\hline \multicolumn{9}{|l|}{ COLEOPTERA } \\
\hline Elmis & 2.2 & 2.2 & & & 2.2 & & & 6.7 \\
\hline Hydraena & 8.9 & 6.7 & 8.9 & 2.2 & & 2.2 & 2.2 & 13.3 \\
\hline Stenelmis & & & & & & & & 2.2 \\
\hline Esolus & & 4.4 & 8.9 & 2.2 & & 4.4 & 8.9 & 4.4 \\
\hline Oulimnius & & & 2.2 & & & & & \\
\hline Dupophilus & & & 2.2 & & & & & \\
\hline Dryops & 2.2 & 2.2 & 13.3 & 2.2 & 4.4 & 4.4 & & \\
\hline Deronectes & & & & & & & 2.2 & \\
\hline \multicolumn{9}{|l|}{ ODONATA } \\
\hline Cordulegaster & & & & & & & & 4.4 \\
\hline CI. OLIGOCHAETA (NF) & 231.1 & 122.2 & 511.1 & 424.4 & 442.2 & 533.3 & 322.2 & 1055.6 \\
\hline \multicolumn{9}{|l|}{ CI. CRUSTACEA } \\
\hline Asellidae (NF) & 6.7 & 15.6 & 26.1 & 19.4 & 13.3 & 6.7 & 22.2 & 62.2 \\
\hline Echinogammarus & & & & & & & & 6.7 \\
\hline
\end{tabular}


Table 2. (Cont.)

\begin{tabular}{|c|c|c|c|c|c|c|c|c|}
\hline & $23 / 11 / 95$ & $6 / 12 / 95$ & 2512195 & 1511196 & $5 / 2 / 96$ & 2912196 & $1 / 4 / 96$ & $4 / 5 / 96$ \\
\hline \multicolumn{9}{|l|}{ Cl. MOLLUSCA } \\
\hline Ancylus (NF) & 26.7 & 13.3 & 8.9 & 22.2 & 4.4 & 11.1 & 8.9 & 28.9 \\
\hline Potamopyrgus (NF) & 17.8 & 4.4 & 6.7 & 15.6 & 31.1 & 13.3 & 11.1 & 17.8 \\
\hline \multicolumn{9}{|l|}{ Cl. TURBELARIA } \\
\hline Polycelis (NF) & & & 2.2 & 2.2 & & 2.2 & & \\
\hline Cl. NEMATODA (NF) & 8.9 & & 2.2 & 15.6 & 6.7 & 6.7 & 20.0 & 2.2 \\
\hline TOTAL & 457.7 & 324.1 & 1186.5 & 1257.2 & 1291.1 & 1324.3 & 1568.8 & 4446.6 \\
\hline Total number of taxa & 17 & 19 & 23 & 21 & 24 & 25 & 25 & 28 \\
\hline NF taxa number & 5 & 4 & 6 & 6 & 5 & 6 & 5 & 6 \\
\hline F taxa number & 12 & 15 & 17 & 15 & 20 & 18 & 20 & 22 \\
\hline
\end{tabular}
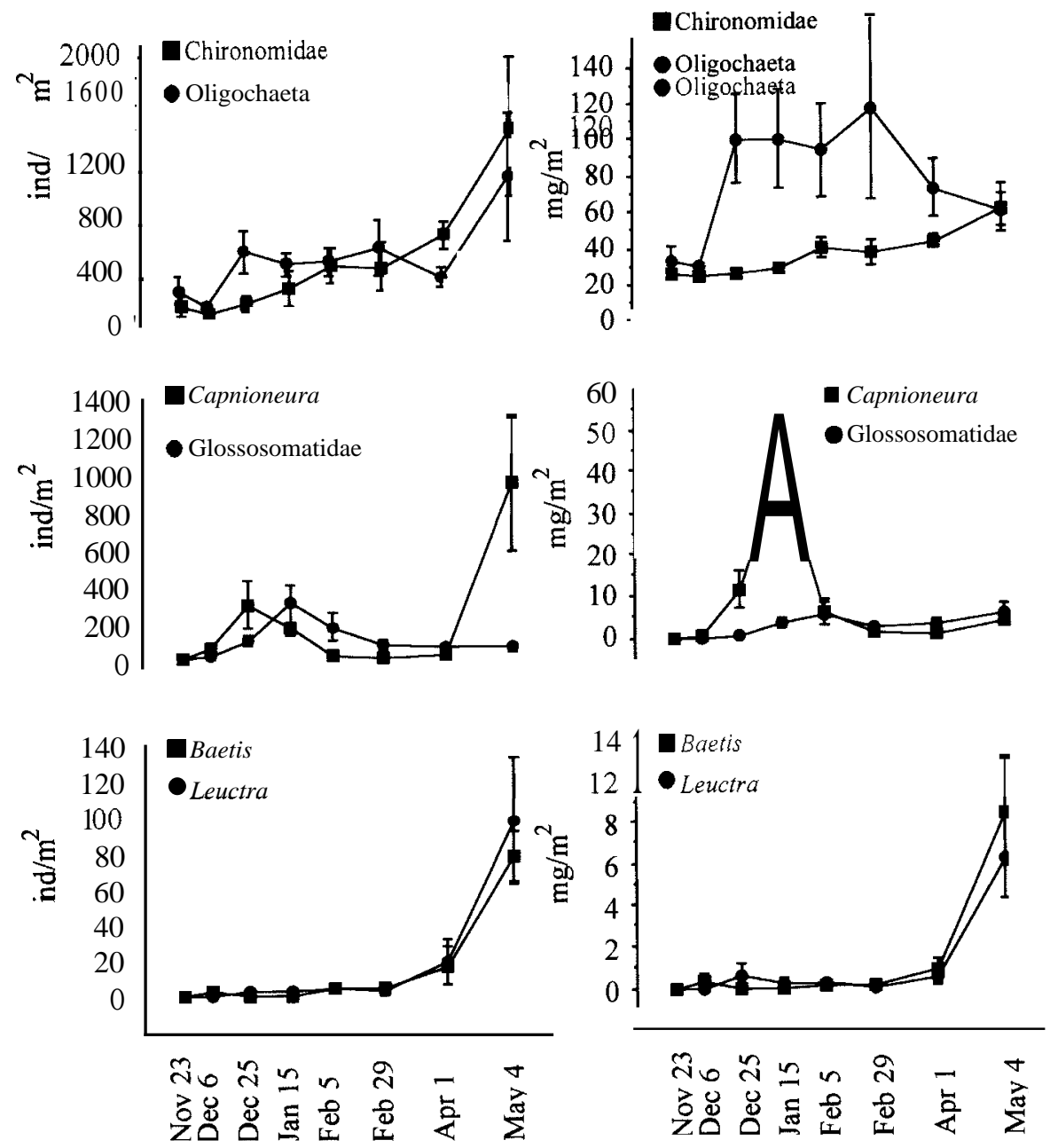

Figure 3. Mean abundance and biomass oí Chironomidae, Oligochaeta, Capnioneura, Cilossosoinatidae, Leuctra and Baetis over the study period (June 1995 to May 1996). Vertical bars are of one standard error at either side of the mean. Abundancia y biomasa medias de Chironomidae, Oligochaeta, Capnioneura, Glossosomatidae. Leuctra y Baetis u lo largo del periodo de estudio. En barras se representa el error estándar 
Among the earlier colonizers, Oligochaeta and Chironomidae were the most abundant. Oligochaeta showed the highest densities (231 ind $\mathrm{m}^{-2}$ ) and biomass $\left(9.29 \mathrm{mg} \mathrm{m}^{-2}\right)$ until the last samplings, when Chironomidae became dominant (Fig. 3). Chironomids were present from the beginning of the study in high densities (113 ind $\mathrm{m}^{-2}$ ) and biomass $\left(1.98 \mathrm{mg} \mathrm{m}^{-2}\right)$, and increased significantly over time (Table 3 ). There were significant variations in the density and biomass of Glossosomatidae and Capnioneura in winter (Fig. 3, Table 3). In spring, later colonizers Baetis, Leuctra and Leptophlebiidae increased significantly in density and biomass as a result of ecclosion of new larvae (Table 3).
Most abundant taxa (i.e. those representing at least $4 \%$ of total density at any sampling date) made up at least $85 \%$ of the total invertebrate density (Fig. 4). At first, oligochaetes and chironomids represented $75 \%$ of the total invertebrate abundance. As re-colonization progressed, other taxa increased their relative importance, and at the end of the study period, a more even community was reached. The dynamics of biomass was different, and at the end of the sampling period, several large-bodied taxa with low densities, such as Cordulegaster, accounted for max. $50 \%$ of the total invertebrate biomass (Fig. 5).

Figure 6 shows the dynamics over time of flying and non-flying invertebrates. At the begin-

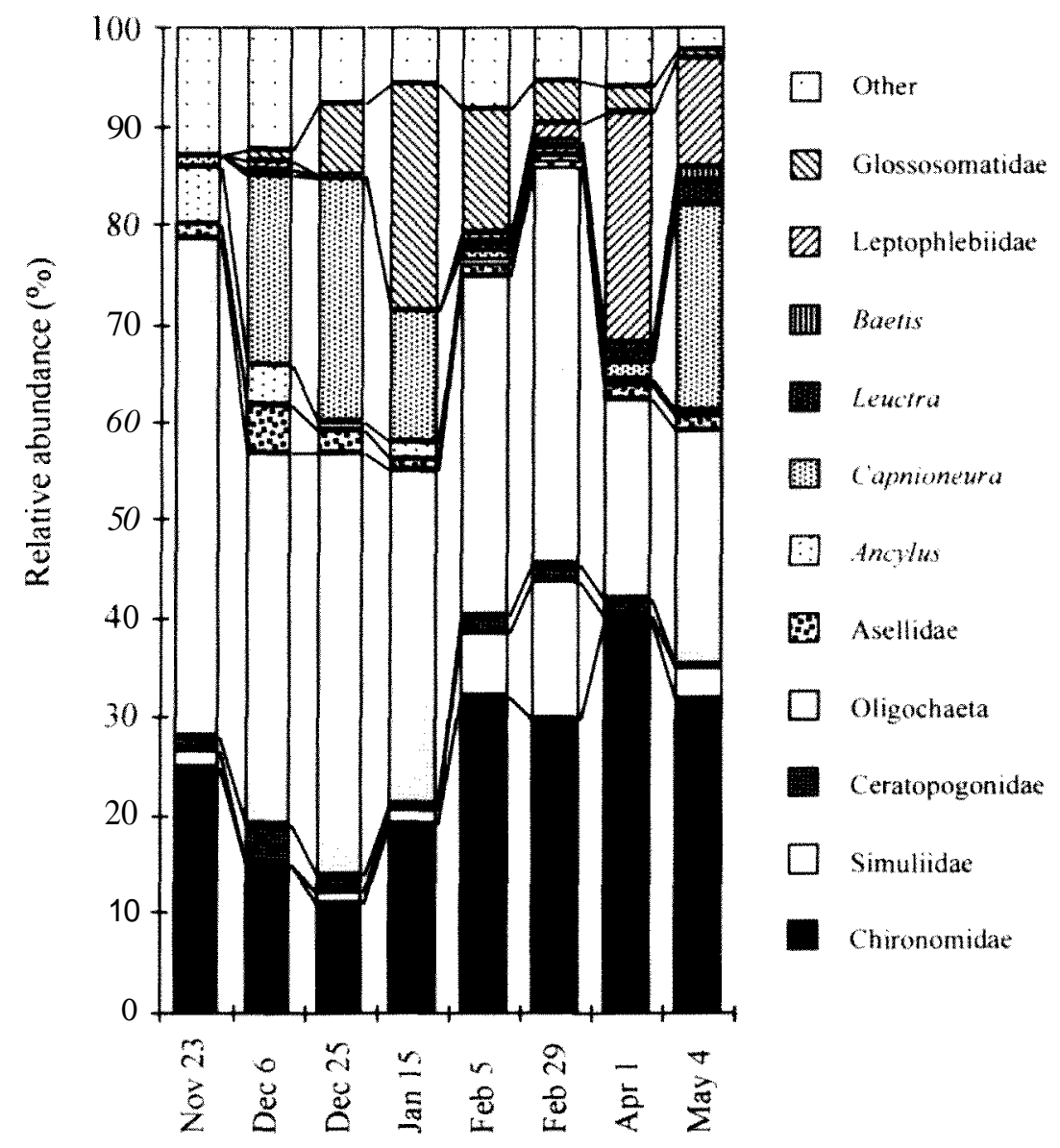

Figure 4. Community dynamics (i.e. changes in relative abundance of taxa) during sampling periods in a first-order stream of the Agüera basin (Northern Spain). Dinúmica de la comunidad en términos de abundancia relativa en los periodos de murstrro. 
ning of the re-colonization, the community was dominated by non-flying taxa $(60 \%$ of the total density and $65 \%$ of the total biomass). However, by the end of the study, flying invertebrates were dominant.

Figure 7 compares community structure of the re-colonizing invertebrates with that of the community during a previous study at the same site. Macroinvertebrate distribution was more homogeneous in 1992-1993, when the different taxa showed quite similar relative abundances. Major differences between both communities were apparent in December, when taxa richness was low and relative abundance of the Oligochaeta was high in the re-colonizing community. In
May, the communities were more similar in both composition and relative abundance of each taxon. The main difference between the communities in both studies during May was the higher abundance of Capnioneura and the lower of Ecdyonurus in May 1996.

\section{DISCUSSION}

Natural disturbances such as variations in water flow (i.e. floods, droughts) affect the structure and dynamics of macroinvertebrate communities (Hildrew \& Townsend 1986; Lake \& Schreiber, 1991; Palmer et al., 1995; Coimbra et al., 1996;

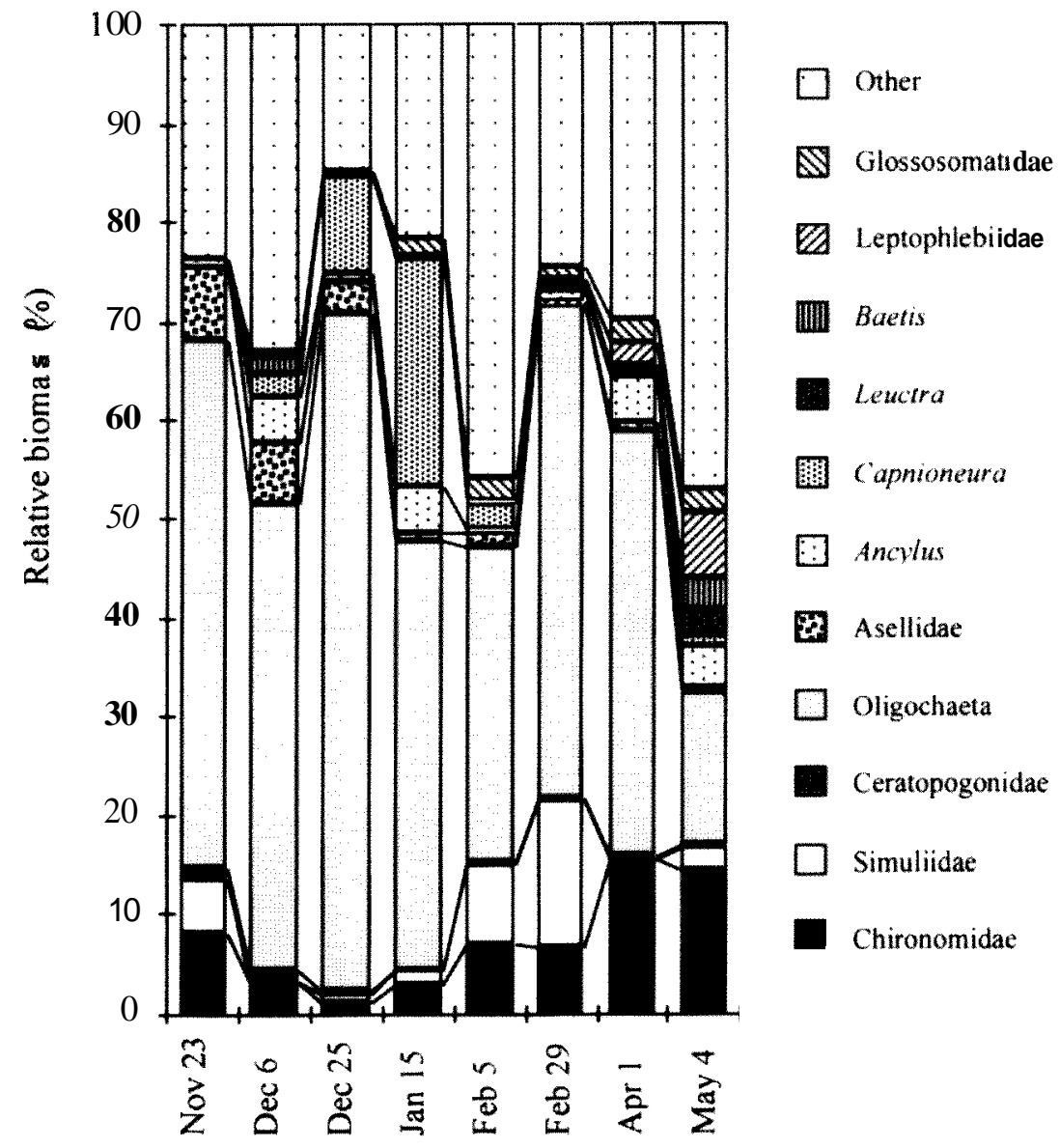

Figure 5. Community dynamics (i.e. changes in relative biomass) during sampling periods in a first-order streain of the Agüera basin (Northem Spain). Dinámica de la comunidad en términos de biomasu relativa en los periodos de muestreo. 
Table 3. Summary of analysis ofvariance results (time factor) on the density and biomass of total inveriebrates and on the most abundant groups. Multiple comparisons between sampling dates were performed using Tukey tests. Numbers 1 to 8 are sampling occasions. Means underlined are not significantly different. Resultado de los análisis de la varianza (factor tiempo) de la densidad y biomasa del total de invertebrados y de los grupos más abundantes. Los test de comparaciones múltiples se realizaron con el test de Tukey. Los numeros de! I al 8 indican muestreos. Se unen con una linea aquellos muestreos entre los que no hay diferencias. n.s.: no significativo.

\begin{tabular}{|c|c|c|c|}
\hline & DEN & SITY & BIOMASS \\
\hline & $p$ value & Tukey test & $p$ value Tukey test \\
\hline TOTAL & $\mathrm{p}<0.001$ & $21 \underline{345678}$ & $\mathrm{p}<0.00121374658$ \\
\hline Chironomidae & $p<0.001$ & $21 \underline{346578}$ & $p<0.001 \quad 23146578$ \\
\hline Simuliidae & $\mathrm{p}<0.001$ & 21743658 & $\mathrm{p}<0.05 \quad 27 \underline{\underline{48655}}$ \\
\hline Ceratopogonidae & n.s. & & n.s. \\
\hline Capnioneura & $\mathrm{p}<0.001$ & 16572438 & $p<0.001 \quad 17268534$ \\
\hline Leuctra & $p<0.001$ & $1234 \overline{5678}$ & $p<0.001 \quad 12654738$ \\
\hline Buetis & $\mathrm{p}<0.001$ & $\underline{13425678}$ & $p<0.001 \quad 13456278$ \\
\hline Leptophlebiidae & $\mathrm{p}<0.001$ & 13425678 & $p<0.001 \quad 13254678$ \\
\hline Glossosomatidae & $\mathrm{p}<0.001$ & 12678354 & $\mathrm{p}<0.05 \quad 12367458$ \\
\hline Oliogochaeta & n.s. & & n.s. \\
\hline Asellidae & n.s. & & n.s. \\
\hline Ancylus & n.s. & & n.s. \\
\hline
\end{tabular}

Matthaei et al., 1997) by reducing species richness and abundance (Boulton et al., 1992; Fjellheim et al., 1993; Miller \& Golladay, 1996; Maltchik \& Silva-Filho, 2000; García-Criado \& Fernández-Alaez, 2001). In the Jerguerón stream, taxa richness was very low in the hyporheic zone when the channel was dry. A month before the flow was re-established, few taxa (Chironomidae, Ceratopogonidae, Odonata, Oligochaeta and Mollusca) were found, most of thein represented by individuals of small size. As predisturbance conditions were restored, there was a tendency to increasing the number of taxa (Malmqvist et al., 1991; Boulton \& Lake, 1992). Only two groups, Oligochaeta and Chironomidae, represented almost $75 \%$ of total density at the beginning of this stage. Dominance of few groups is a common feature of the macroinvertebrate community in initial stages of the re-colonization process (Ladle et al., 1980). These pioneer taxa are able to persist in moist sediments in an active form, as eggs or in diapause phases
(Yount \& Niemi, 1990; Del Rosario \& Resh, 2000). Migration strategies, such as drift and oviposition, would not be possible at this early stage of the re-colonization because upstream sources of organisms would be scarce (Cushing $\&$ Gaines, 1989). Also, it is likely there are few ovipositing adults in November. Non-flying taxa (e.g. Oligochaeta and Mollusca) showed high resistance to drought. They were present in the hyporheic samples and appeared at the beginning of the re-colonization process. Boulton et al. (1991) and Boulton \& Stanley (1995) pointed out that Oligochaeta usually resist drought periods in moist refuges of the hyporheic zone. The same could be said of Mollusca (Boulton 1989). On the other hand, chironomids have been categorised as very resilient organisms (Palmer et al., 1995). The high tolerance of several chironomid species to desiccation (Boulton, 1989), owing to their

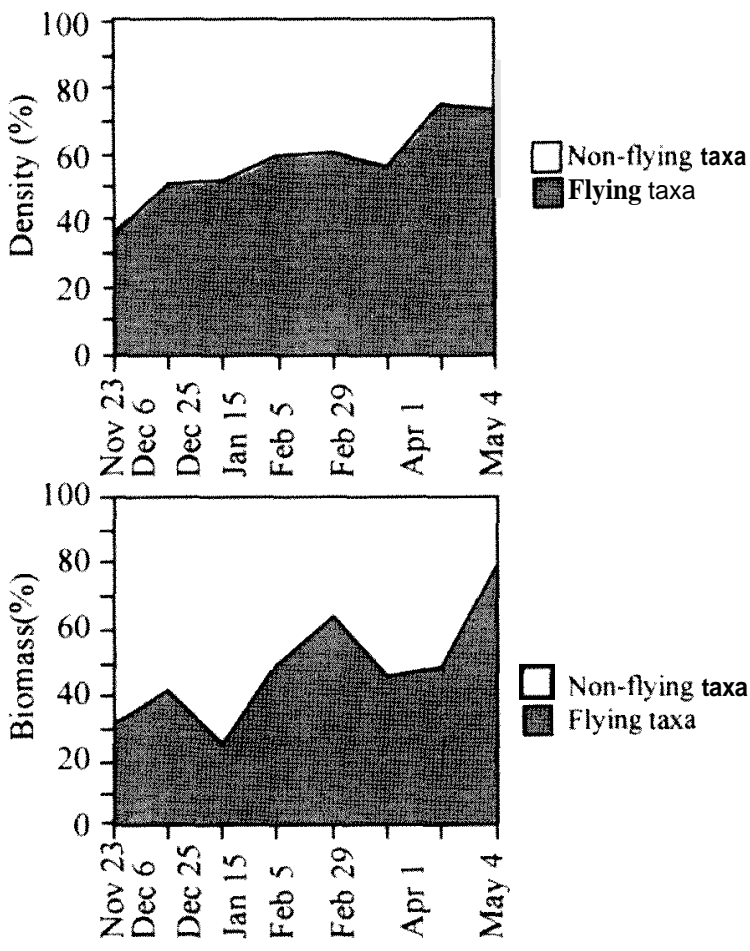

Figure 6. Changes in relative abundance and biomass of flying and non-flying taxa during sampling periods in a first-order stream of the Agüera basin (Norihern Spain). Cambios temporales de la abundancia relativa y la biomasa de taxones voladores y no voladores. 
production of resistant eggs; high developmental rates and that they are multivoltine organisms (Gray, 1981) allows this group to rapidly colonize areas (Malmqvist et al., 1991; Katano et al., 1998). We found individuals which had reached the pupal stage only 13 days after the start of the study. As a result, chironomids could colonize stream habitats very quickly.

The appearance of Capnioneura, Simuliidae and Glossosomatidae and the hatching of new generations lead to an increase in the density and biomass of the macroinvertebrate community over time, which is a trend that has often been observed in streams (e.g. Whiles \& Wallace, 1995; Nelson \& Roline, 1996).

The community structure at the end of the study period, in May, was comparable to that recorded in a previous survey (May 1993). The main differences between both surveys were in terms of presence or absence of groups, rather

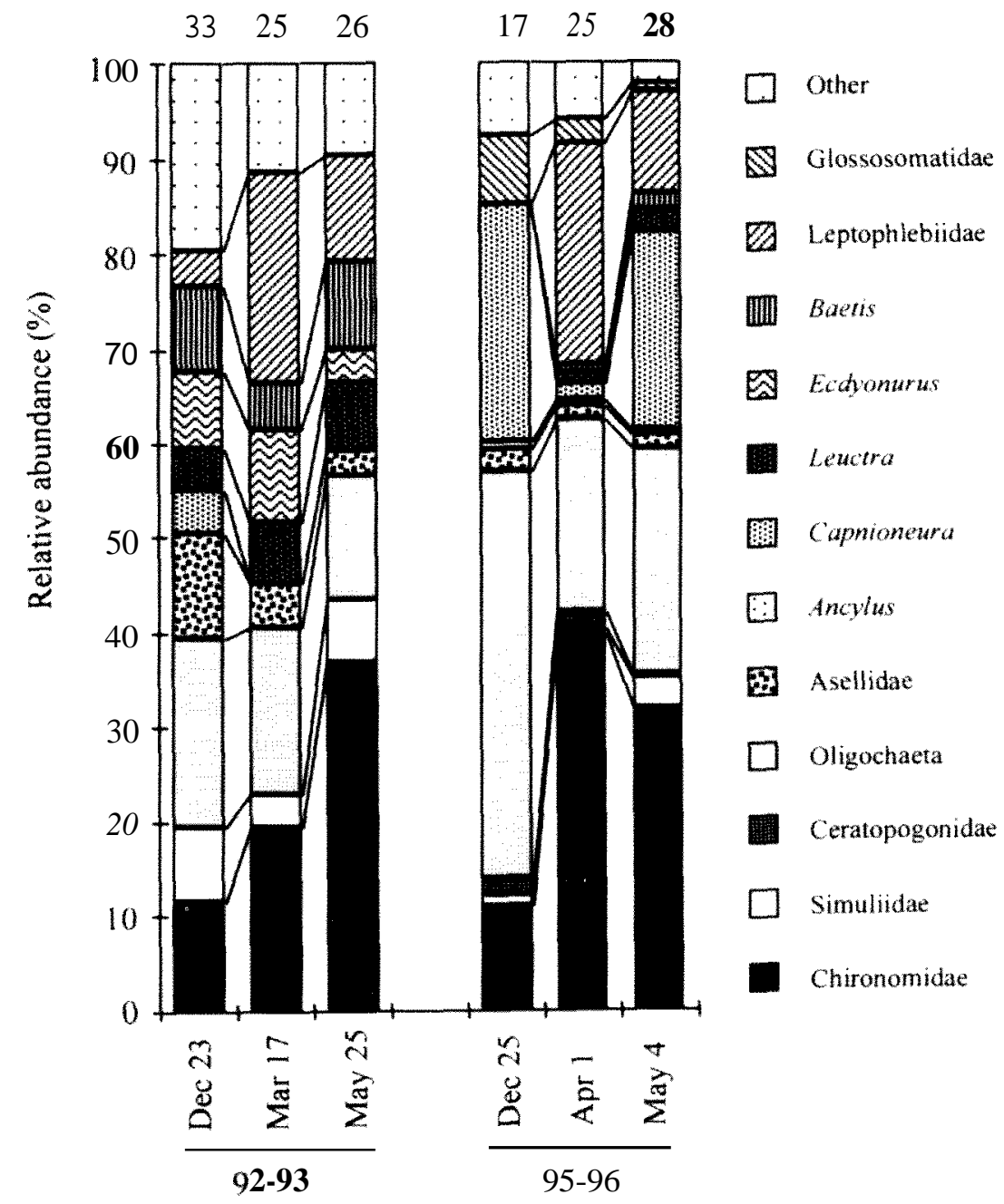

Figure 7. Comparison between the community structure (i.e. relative abundance of taxa) during the study period (June 1995 10 May 1996) and duriiig a previous survey (1992-1993). Total number of taxa in each sampling date is indicated above thc corresponding columns. Comparación de la estructura de la comunidad (en términos de abundancia relativa) del periodo de estudio y una comunidad previa de $1992-$ 1993. Se indica encima de cada barra el número de taxones presentes en cada muestreo. 
than in the relative abundance of taxa. However, Ecdyonuvus, Leuctra and Baetis were relatively more abundant in the community of 1993. It has been pointed out that heptageniids are slow colonizers (MacArthur \& Barnes, 1985), and this could explain the low densities of Ecdyonuvus registered in the stream in the present study. On the other hand, Glossosomatidae and Capnioneu$r a$ were relatively more abundant during the recolonization process. These taxa could have been favoured by the season in which the disturbance occurred (see Yount \& Niemi, 1990; McKay, 1992) and by the phenology of their life histories.

Collectors are usually the pioneers in the recolonization of stream habitats. Scrapers, requiring periphyton growth, arrive later. Shredders and predators tend to appear the last in the re-colonization sequence (Gore, 1982; MacKay, 1992). In the Jerguerón stream, collectors dominated, but no pattern of re-colonization was apparent for the other functional groups (i.e. shredders, scrapers and predators).

A continuous increase in the number of taxa and in total macroinvertebrate density occurred. The first stages of re-colonization of the stream by macroinvertebrates reflected the dominance of a few drought-resistant taxa. By the end of re-colonization the macroinvertebrate community displayed a more even distribution.

\section{ACKNOWLEDGEMENTS}

We thank J.M. González for field support and help with the identification of macroinvertebrates. Research was supported by the General Bureau for Scientific and Technical Research (Central Government, Madrid; project DGICYT, PB 95-0498).

\section{REFERENCES}

ANGRADI, T. R. 1997. Hydrologic context and macroinvertebrate community response to floods in an Appalachian headwater stream. The Am. Mid. Nat., 138: 371-386.

BASAGUREN, A., A ELÓSEGUI \& J. POZO. 1996 Changes in the trophic structure of benthic macroinvertebrate communities associated with food availability and stream flow variations. Znt. Revue. ges. Hydrobio., 81 : 79-91.

BOULTON, A. J. 1989: Over-summering refuges of aquatic macroinvertebrates in two intermittent streams in central Victoria. Trans. R. Soc. S. Aust., 113: 23-34.

BOULTON, A. J. \& P. S. LAKE. 1992. The ecology of two intermittent streams in Victoria, Australia. III. Temporal changes in faunal composition. Freshwat. Biol., 27: 123-138.

BOULTON, A. J. \& E .H. STANLEY. 1995. Hyporheic processes during flooding and drying in a Sonoran Desert stream. II. Faunal dynamics. Arch. Hydrobiol., 134: 27-52.

BOULTON, A. J., S. E. STIBBE, N. B. GRIMM \& S. G FISHER. 1991. Invertebrate re-colonization of small patches of defaunated hyporheic sediments in a Sonoran Desert stream. Freshwat. Biol., 26: 267-277.

BOULTON, A. J., C. G. PETERSON, N. B. GRIMM \& S. G. FISHER. 1992. Stability of an aquatic macroinvertebrate community in a multiyear hydrologic disturbance regime. Ecology, 73: 2 192-2207.

COIMBRA, C. N., M.A.S. GRAÇA\& R. M. CORTES. 1996. The effects of a basic effluent on macroinvertebrate community structure in a temporaly Mediterranean river. Environ. Poll., 94: 301-307.

COLLIER, K. J. 1995. Environmental factors affecting the taxonomic composition of aquatic macroinvertebrate communities in lowland waterways of Northland, New Zealand. N. Zealand J. Mar. Freshwat. Res., 29: 453-465.

CUSHING, C. E. \& W. L. GAINES. 1989. Thoughts on re-colonization of endorheic cold desert springstreams. J. N. Am. Benthol. Soc., 8: 277-287.

DEL ROSARIO, R. \& V. H. RESH. 2000. Invertebrates in intermittent and perennial streams: is the hyporheic zone a refuge from drying? $J . N$. Am. Benthol. Soc, 19 (4): 680-696.

ELÓSEGUI, A. \& J. POZO. 1994. Spatial versus temporal variability in the physical and chemical characteristics of the Agüera stream (Northern Spain). Acta Oecologica, 15: 543-559. 
FJELLHEIM, A., J. HAVARDSTUN, G. G. RADDUM \& O. A. SCHNELL. 1993. Effects of increased discharge on benthic invertebrates in a regulated river. Reg. Riv. :Res. \& Man., 8: 179-187.

GARCÍA-CRIADO, F. \& M. FERNÁNDEZ-ALÁEZ. 2001. Hydraenidae and Elmidae assemblages (Coleoptera) from a Spanish river basin: good indicators of coal mining pollution? Arch. Hydrobiol., 150: 641-660.

GORE, J. A. 1982. Benthic invertebrate colonization: source distance effects on community composition. Hydrobiologiu, 94: 183-193.

GRAY, L. J. 1981. Species composition and life histories of aquatic insects in a lowland Sonoran desert stream. Am. Mid. Nat., 106: 229-242.

GRISWOLD, B. L., C. J. EDWARDS \& L. C. WOODS. 1982. Re-colonization of macroinvertebrates and fish in a channelized stream after a drought. Ohio J. Sci., 82: 96-102.

HILDREW, A. G. \& C. R. TOWNSEND. 1986. Organization in freshwater benthic communities. In: Organization of communities, past and present. Gee, J. H. R. \& Giller, P. S. (ed), Blackwell Scientific Publications. 347-371 pp.

ILG, C., E., CASTELLA, B. LODS-CROZET \& P. MARMONIER. 2001. Invertebrate drift and physico-chemical variables in the tributaries of the Mutt, a Swiss glacial stream. Arch. Hydrobiol., 151:335-352.

KATANO, O., J. TOI, K. MAEKAWA. \& K. IGUCHI. 1998. Colonization of an artificial stream by fishes and aquatic macroinvertebrates. Ecol. Res., 13:83-96.

LADLE, M., J. S. WELTON \& J. A. B . BASS. 1980. lnvertebrate colonization of the gravel substratum of an experimental recirculating channel. Hol. Ecol., 3: 116-123.

LAKE, P. S. \& E. S. G. SCHREIBER. 1991. Colonization of stones and recovery from disturbance: An experimental study along a river. Verh. Internat. Verein. Limnol., 24: 2061-2064.

MACKAY, R. J., 1992. Colonization by lotic macroinvertebrates: a review of processes and patterns. Can. J. Fish. Aquat. Sci., 49: 617-628.

MALMQVIST, B. \& G. ENGLUND. 1996. Effects of hydropower-induced flow perturbations on mayfly (Ephemeroptera) richness and abundance in north Swedish river rapids. Hydrobiologia, 341 : 145-158.

MALMQVIST, B., S. RUNDLE, C. BIRSNMARK \& A. ERLANDSSON. 1991. Invertebrate colonization of a new, man-made stream in southern Swden. Freshwat. Biol., 26:307-324.
MALTCHIK, L. \& M.I. SILVA-FILHO. 2000. Resistance and resilience of the macroinvertebrate community to disturbance by flood and drought in a Brazilian semiarid ephemeral stream. Acta Biologica Leopoldensia, 22: 171-184.

MATTHAEI, CHD, U. UEHLINGER \& A. FRUTIGER. 1997. Response of benthic invertebrates to natural versus experimental disturbances in a Swiss prealpine river. Freshwat Biol., 37: 61-77.

MATTHAEI, C. D., K. A. PEACOCK \& C. R. TOWNSEND. 1999. Scour and fill patterns in a New Zealand stream and potential implications for invertebrate refugia. Freshwat Biol., 42: 41-57.

MCARTHUR, J. V. \& J. R. BARNES. 1985. Patterns of macroinvertebrate colonization in an intermittent rocky mountain stream in Utah. Great Basin Naturalist, 45:117-123.

MILLER, A. M. \& S. W. GOLLADAY. 1996. Effects of spates and drying on macroinvertebrate assembrages of an intermittent and a perennial prairie stream. J N Am Benthol Soc., 15: 670-689.

NELSON, S. M. \& R. A. ROLINE. 1996. Recovery of a stream macroinvertebrate community from mine drainage disturbance. Hydrobiologia, 339: 73-84.

PALMER, M. A., P. AERNSBURGER, P. S. BOTTS, C. C HANKENKAMP \& J. W. REID. 1995. Disturbance and the community structure of stream invertebrates: patch-specific effects and the role of refugia. Freshwat Biol., 34: 343-356.

PUIG, M. A. 1983. Efemeropteros y plecópteros de los ríos catalanes Tesis Doctoral. Universidad de Barcelona, $582 \mathrm{pp}$.

RESH. V. H., A. V. BROWN, A. P. COSICH, M. E. GURTZ, H. W. LI, G. W. MINSHALL, S. R. REICE, A. L. SHELDON, J. B. WALLACE \& R. WISSMAR. 1988. The role of disturbance in stream ecology. J N Am Benthol Soc., 7: 433-455.

RICHAUX, P. 1982. Introduction practique a la systematique des organismes des eaux continentales françaises. 2. Coleopteres aquatiques (genes: adultes et larves). Bull Soc Lin Lyon, 4: 105-304.

TACHET, H., M. BOURNAUD \& P. USSEGLIOPOLATERA. 2002. Invertébrés d'eau douce Systématique, biologie, écologie. CNRS éditions. Paris. 587pp

TOWNSEND, C. R. \& A. G. HILDREW. 1994. Species traits in relation to a habitat templet for river systems. Freshwat Biol., 31 : 265-275.

VELASCO, J. \& A. MILLÁN. 1998. Insect dispersal in a drying desert stream: effects of temperature and water loss. Southwestern Naturalist, 43: 80-87. 
WHILES, M. R. \& J. B. WALLACE. 1995. Macroinvertebrate production in a headwater stream during recovery from anthropogenic disturbance and hydrologic extremes. Can. J. Fish. Aquat. Sci., 52: 2402-2422.

WILLIAMS, D. D. 1977. Movements of benthos during the re-colonization of temporary streams. Oikos, 29: 306-312.

WILLIAMS, D. D. 1987. The ecology of temporary waters. Croom Helm, London \& Sidney, Timber Press, Portland, Oregon .205pp.
WILLIAMS, D. D. 1996. Environmental constraints in temporary fresh waters and their consequences for the insect fauna. J. N. Am. Benthol. Soc., 15: 634-650.

YOUNT, J. F. \& G. J. NIEMI. 1990. Recovery of lotic communities and ecosystems from disturbance- a narrative review of case studies. Environ. Man., 14: 547-569.

ZAR, J. H. 1984. Biostatistical Analysis. PrenticeHall Internacional Inc. New Jersey, 718pp. 